AgnieszKa Mazurowska

Uniwersytet Gdański

Katedra Slawistyki

\title{
Ślady przeszłości zachowane w imionach na epitafiach nagrobkowych cmentarza w Baniach Mazurskich
}

Słowa klucze: antroponimy, epitafium nagrobkowe, imiona ukraińskie, Bojkowie, Łemkowie

Przedmiotem artykułu jest analiza imion ludności pochodzenia ukraińskiego, zamieszkującej miejscowość Banie Mazurskie po roku 1947. Materiał został zebrany w wyniku eksploracji terenowej miejscowego cmentarza polsko-ukraińskiego podczas licznych odwiedzin w rodzinnej miejscowości w roku 2006.

Cezura roku 1947 jest nieprzypadkowa, gdyż rozpoczęta w tym czasie akcja „Wisła” otwiera nowy rozdział w powojennej historii badanego terenu. Banie Mazurskie, które do roku 1954 wchodziły w skład powiatu węgorzewskiego, były zamieszkiwane przez ludność polsko- lub niemieckojęzyczną, przeważnie wyznania ewangelickiego. Niektórzy mieszkali tutaj od wieków, a ich korzenie wywodziły się zwykle z Mazowsza. Mogli być również potomkami ludności pochodzenia bałtyckiego (głównie litewskiego), o czym świadczą spotykane tu nazwiska typu: Paulukanis, Jodzis, Żemajtys itp. (Mazurowska 2005: 1).

W krótkim czasie badany teren stał się nową ojczyzną dla przesiedleńców z Wileńszczyzny i Grodzieńszczyzny, mieszkańców Suwalszczyzny oraz mniejszości ukraińskiej (w Baniach Mazurskich osiedlono około czterech z ośmiu tysięcy Ukraińców zamieszkałych w powiecie węgorzewskim). Ta niezwykła z socjologicznego punktu widzenia sytuacja stworzyła swoisty „tygiel” pod względem etnicznym i kulturowym. W obrębie jednej miejscowości zamieszkali bowiem wy- 
znawcy Kościoła bizantyjsko-ukraińskiego, prawosławnego, katolickiego oraz ewangelickiego. Ludzie, których dzieliło wszystko, musieli nagle znaleźć wspólny kod językowy. Nawet mniejszość ukraińska, choć postrzegana przez innych przybyszów jako jednolita grupa, w rzeczywistości składała się z Bojków, Łemków i Dolinian. Nie była to, podobnie jak poprzednie grupy, ludność jednorodna pod względem narodowym, wyznaniowym i językowym. Wśród przymusowych osiedleńców dominowało wyznanie greckokatolickie, aczkolwiek pojawiali się także wyznawcy prawosławia. Nie było wśród nich natomiast przedstawicieli religii rzymskokatolickiej.

Najbardziej wyrazistą grupę stanowiły rodziny Łemków i Bojków, poprzednio zamieszkujące Nadsanie (tereny po lewej stronie Sanu zamieszkiwali Bojkowie, a po prawej Łemkowie, posługujący się własnym etnolektem ${ }^{1}$ ). Na nowym terenie zbliżyła ich akcja przesiedleńcza, a dodatkowym łącznikiem była tęsknota za krajobrazem utraconej małej Oj c zy zny, fakt, że byli oni Horcami, jak sami o sobie mówili (Mazurowska 2005: 2).

Omawiany cmentarz, znajdujący się tuż przy kościele należącym obecnie do parafii rzymskokatolickiej pod wezwaniem św. Antoniego Padewskiego, był pierwotnie cmentarzem ewangelickim, choć z tego okresu przetrwało do dziś niewiele nagrobków. Nieliczne, z tych na których zachowały się tablice, pochodzą z pierwszej połowy wieku XX.

Wskutek niewłaściwie prowadzonej polityki narodowościowej na tzw. Ziemiach Odzyskanych ludność przesiedlona po II wojnie światowej na tereny Mazur Wschodnich czuła wrogość wobec byłych mieszkańców tych ziem, posługujących się językiem niemieckim. Ludność, która najczęściej osiedlała się na obszarach wiejskich w powiecie gołdapskim i węgorzewskim, nie zdawała sobie sprawy, że mazurscy ewangelicy posługujący się pełnym germanizmów dialektem mazurskim mogą być, tak jak i oni, Polakami. Dogodna lokalizacja cmentarza w Baniach Mazurskich sprawiła, że niemieckojęzyczne nagrobki zniszczono, a właściwie rozkradziono, gdyż w trudnych latach powojennych kamieniarze ponownie wykorzystywali elementy nagrobków niemieckich, np. zapisując tablice $\mathrm{z}$ drugiej strony (tym razem w języku polskim lub ukraińskim), a nowe nagrobki umieszczano w miejscu dawnych.

$\mathrm{Na}$ szczególną uwagę zasługują nagrobki greckokatolickie, gdyż ludność ukraińska na terenie gminy stanowiła prawie $80 \%$, co sprawiło, że miejscowość

1 Przez et nolekt rozumiem język lub dialekt, używany na danym terenie przez daną społeczność. Szerzej na temat języka zob. Michna (1995). 
zaczęto nazywać stolicą polskich Ukraińców - U kra in o w e m. Większość antroponimów nagrobkowych zapisana jest grażdanką w pełnym błędów języku ukraińskim. Trzeba tu podkreślić, że już od początku chrześcijaństwa imiona używane na Rusi miały cechy fonetyczne charakterystyczne dla wyrazów zapożyczonych z języka średniogreckiego. M. Łesiów (1988: 11-13) do najważniejszych cech fonetycznych zalicza następujące.

- Wymowę średniogreckiej $B$ (bety) jako [w], co przeciwstawia się łacińskozachodnioeuropejskiemu dźwiękowi $[b]$ w tych samych rdzeniach wyrazowych, np. Zynowij (Zenobiusz), Warwara (Barbara),

- Wymowę średniogrecką th (thety) jako [f], która mogła też występować w postaci $[p]$ i $[c h v]$, co przeciwstawia się zachodniemu $[t]$ (th), np. Fedir (Teodor).

- greckąs (sigmę) w pozycji między dwiema spółgłoskami w imionach wschodniosłowiańskich realizowano jako $[s]$, co przeciwstawia się brzmieniu imion z tradycji łacińskiej z [-z-], np. Josyp (Józef), Wasyl (Bazyli).

- Wymowę średniogrecką e (ety) w imionach rusko-bizantyjskich jako [i], [y], która przeciwstawia się odpowiednikom polsko-łacińskim z -e-, np. Danyło (Daniel), Hryhorij (Grzegorz).

- Warto jeszcze wspomnieć o rozróżnieniu w imionach - $k$ - (wymowa grecka i klasyczna łacińska) w tradycji cerkiewnoruskiej, np. Kyryło przeciwstawione późnołacińskiej wymowie z palatalizacją - $k$ - jako - $c$ - (Cyryl).

Trzeba wziąć pod uwagę, że Ukraińcy (przede wszystkim Bojkowie² i Łemkowie) przed wojną zamieszkiwali głównie tereny wiejskie południowo-wschodnich kresów Rzeczpospolitej. W większości byli to chłopi bez wykształcenia, którzy posługiwali się jedynie gwarą swojej wsi. Ponadto pracownicy Urzędu Stanu Cywilnego i księża katoliccy (trzeba pamiętać, że msze odprawiane w obrządku greckokatolickim były zakazane na badanym terenie do 1957 roku) nie znali literackiego języka ukraińskiego, więc antroponimy spotykane w dokumentach są to najczęściej imiona polskie zapisane grażdanka, formy rosyjskie bądź gwarowe odpowiedniki imion ukraińskich.

${ }^{2}$ Część Łemków zamieszkujących tereny południowo-wschodniej Polski nie uważa się za Ukraińców, tylko za odrębny naród rusiński. Po przesiedleniu na teren Bań Mazurskich, gdzie znaleźli się w grupie mniejszościowej (dominowali Bojkowie i Polacy), nieliczni na tym terenie Łemkowie zyskali nową u kraińską świadomość narodową. Najważniejsza bowiem stała się dla nich opozycja: Swoi (ludność przesiedlona w wyniku akcji „W”) - Obcy (Polacy, Zabużanie, Mazurzy, Niemcy). 
W nagrobkowych antroponimach cmentarza w Baniach Mazurskich pojawiają się dwa rodzaje błędów:

- w grafii najczęściej mylone są litery polskie i ukraińskie, np. Dимитро, Дмутро, Dимитрій, Dар’іуш, Јван, Јвась, Міхапло, Миколай, Петго, Стефап, Теодор, Володимир, Јрина, Јузефа, Катаруна, Рараскевя, - ukraińskie i rosyjskie, np. Апам, Анdріи, Евген, Евстахи, Григоріи, Юріи, Эвдокія, Евфемя, Евфрузина, Евгенія, Евгеня, Евстахія, Ева, Бера.

Bardzo możliwe, że w przypadku niektórych zapisów, błędy wynikały z nieznajomości grażdanki przez kamieniarza bądź też z jego nieuwagi, czego mogą dowodzić np. błędy w imionach: Юріи, Михаило, Міхапло, Миколаи. Szczególnie często nieprawidłowe zapisy imion dotyczą liter nieznanych alfabetowi łacińskiemu, takich jak: $Є, Ю, Я$, nр. Яарослав, Юури, Ева.

Na najstarszych nagrobkach napisy ryto w kamieniu bądź malowano je farbą we wnęce pomnika i umieszczano za szybą, by uchronić tekst przed szkodliwymi warunkami atmosferycznymi.

W imionach zmarłych, pochowanych na Cmentarzu Komunalnym w Baniach Mazurskich, można zaobserwować następujące tendencje.

- Przede wszystkim większość imion zapisana jest w formie oficjalnej (urzędowej). W tej grupie można wyróżnić imiona typowo ukraińskie, tzn. takie, których postać metrykalna jest niezmieniona, identyczna $\mathrm{z}$ formami zapisanymi w słowniku imion słowiańskich, nр.: Олександр, Олекса, Андрій, Василь, Данило, Нпат, Іван, Кузьма, Пилип, Юрій.

- W drugiej grupie znalazły się imiona ukraińskie, które uległy procesowi polonizacji, tzn. takie, których ukraińskie brzmienie jest przystosowane do zasad polskiej fonetyki i ortografii, nр.: Dар'іуш, Александер, Еміл, Міхал, Стефан. Niektóre imiona były też zapisywane w wersji rosyjskiej, np.: Александр, Иван, Павел, Симеон, Алекса́ндра, Ева, Екатерина.

Oprócz imion zapisanych w pełnej formie, w dokumentach urzędowych i kościelnych, pojawiają się na nagrobkach imiona w formie potocznej, np. w postaci zdrobnień i spieszczeń. Odnotowane przeze mnie formy hipokorystyczne dotyczą najczęściej nagrobków małych dzieci, np. Петрусь, Панько, Тадзіо, rzadziej osób dorosłych, np. Леся-Маруся ${ }^{3}$. Najczęstsze sposoby ich powstawania to skracanie imienia i derywacja sufiksalna.

Bardzo często kłopoty sprawia ustalenie, który z członów epitafium onomastycznego odnosi się do imienia, a który do nazwiska. Dopiero weryfikacja an-

3 Świadczą o tym daty życia i śmierci. 
troponimu w słownikach nazwisk bojkowskich i łemkowskich rozstrzyga te wątpliwości, gdyż spora grupa nazwisk ukraińskich pochodzi od imion w formie urzędowej lub potocznej, np. Назар Сенько. Poza tym, w przeciwieństwie do nagrobków polskich, nie zawsze zachowano zasadę umieszczania imienia przed nazwiskiem, np. Ліхач Тадзіо.

Ze względu na fakt, iż materiał zebrany został w wyniku eksploracji nekropolii (a więc dotyczy w większości osób urodzonych w końcu wieku XIX bądź w I poł. wieku XX), sporą część stanowią imiona cerkiewne, charakterystyczne dla kręgu kultury bizantyjskiej, które ze względu na panującą modę językową są dziś rzadko używane. Przed analizą materiału warto wspomnieć o badaniach M. Łesiowa (1988: 9-10), który sporządził wykaz 100 najpopularniejszych imion używanych przez Ukraińców. Spośród wymienionych przez wspomnianego badacza antroponimów na badanej nekropolii znalazły się:

- imiona o etymologii greckiej: Aleksander, Andrij, Dmytro, Fedir, Hnat, Jewhen, Jurij, Kuźma, Mikołaj, Mykyta, Makar, Oteksij, Pantelejmon, Petro, Prokip, Pylyp, Stefan, Teodor, Wasyl, Zynowij,

- imiona o etymologii łacińskiej: Julian, Maksym, Pawło, Roman, Wasilij,

- imiona o etymologii starohebrajskiej: Adam, Danyto, Ilja (Il'ko), Iwan, Josyp, Mychajło, Semen (Semko).

Frekwencja imion męskich i żeńskich została obliczona tylko na podstawie zapisów cyrylickich imion zamieszczonych w dwóch tabelach (oddzielnie dla imion męskich i żeńskich) i podzielonych według kryterium daty urodzenia.

1. Na nekropolii w Baniach Mazurskich najstarsze nagrobki należą do osób urodzonych w latach 1850-1869, czyli dopiero w II połowie XIX wieku. Najstarsze zanotowane imiona: Dmytro, Mychajto, Mykołaj; Anastasija, Anna, Marija.

2. Najstarsze imiona, które zanikły po II wojnie światowej: a) męskie: Adolf, Eljasz, Ewstachij, Hnat, Il'ko, Kosma, Makar, Mikołaj, Pamfil, Pańko, Prokop, Pylyp, Symeon, Teodor, Trofim, Wasilij; b) żeńskie: Jefemija, Fenna, Jefrosyna, Jevdokija, Luba, Pelagia, Petronelja, Rozalija, Teodora.

3. Imiona, które pojawiły się po II wojnie światowej: Adam, Dariusz, Myrosław, Roman, Stawomyr, Stanisław, Tadeusz; Bożena, Danuta, Darija, Krystyna, Paulina, Teresa.

4. Na cmentarzu zanotowano 44 imiona męskie i 41 żeńskich.

5. Najpopularniejsze imiona: I. Iwan (57), Mychajło (45), Stefan (37), Petro (22), Dmytro (20), Mykołaj (15), Teodor (13), Andrij (10), Wasilij (9), Oteksandr (8); 
II. Marija (50), Anna (49), Kateryna (33), Jewa (17), Paraskowija (16), Anastasija (15), Sofija (9), Stefanija (6), Justyna, (5), Tekla (5).

6. Wśród 10 najpopularniejszych imion odnotowanych na nagrobkach znajduja się stare imiona, które zanikły do wybuchu II wojny światowej: Paraskowija, Anastasija.

Popularność wśród ludności ukraińskiej imion pochodzenia greckiego (przeważająca większość) i starohebrajskiego dowodzi ciagłości tradycji Kościoła bizantyjskiego u narodów słowiańskich (w przeciwieństwie do imion polskich, gdzie przeważa tradycja łacińska). Pomimo to, że obecnie wśród mniejszości ukraińskiej spada popularność imion cerkiewnosłowiańskich, tradycyjne wydawnictwa ukraińskie, np. kalendarze, zachęcają Ukraińców do nadawania dzieciom imion tzw. kanonicznych, czyli świętych. Badacze tacy jak M. Łesiów i Z. Abramowicz podkreślaja, że na terenach, gdzie występowała ludność mieszana polsko-ukraińska lub polsko-białoruska, często spotykamy wzajemne wpływy różnych systemów antroponimicznych. Stąd tak duża liczba polskich imion noszonych przez mniejszość ukraińska.

Słowotwórcza analiza materiału onomastycznego dowodzi, że do najbardziej powszechnych sposobów powstawania wariantów imion należą: skrócenia bezsufiksalne dla imion żeńskich: Jewhenija: Jewhenia, Jefrosynija: Jefrozyna, Julija: Julja, Marija: Marja, Fenenna: Fenna, Natalija: Natalja, Paraskowija: Paraskewja, Teodozija: Teodozja, Sofija: Sofja, Jefymija: Jefemja, a dla imion męskich zmiana paradygmatu: Danyło: Danyjit, Dmytro: Dymytrij, Mychajło: Michat // Mychajit, Pawło: Pawet. Oprócz tego frekwencję różnych form zwiększa fakt, że badano imiona osób urodzonych po roku 1850 aż do roku 1957 i później (do lat osiemdziesiątych i dziewięćdziesiątych XX wieku). Tak duża rozpiętość czasowa spowodowała, że na nekropolii możemy odnaleźć staroukraińskie lub staroruskie formy imion oraz formy charakterystyczne dla współczesnego języka ukraińskiego, np.: Josyp: Josyf, Marija: Maria, Stefan: Stefan.

Zbyt mała liczba form hipokorystycznych na nekropolii nie pozwala wysnuć zbyt daleko idących wniosków w zakresie sposobu tworzenia zdrobnień: zauważono jedynie tworzenie tego typu form za pomocą typowego dla języka ukraińskiego sufiksu -ko: np. Il'ko od Ilia, Sieńko od Semen. Współcześnie antroponimy utworzone za jego pomoca, tak charakterystyczne dla języka ukraińskiego, występują na pograniczu polsko-czesko-słowackim i polsko-ruskim. Stąd u tak zróżnicowanej ludności pogranicza pojawiają się formy imion o proweniencji słowackiej, np. Kataryna, lub forma Danyjit, charakterystyczna dla języka rosyj- 
skiego i rumuńskiego (Maliszewska 1993: 174-175). Zanotowano tylko jeden sposób tworzenia żeńskiej formy hipokorystycznej za pomocą formantu -usja: Marusia od Marija> Marja> Marusia. Za pomocą formantu -ś powstał Iwaś. Pozostałe formy zdrobniałe, takie jak: Tadzio, Marysia, powstały w sposób typowy dla systemu języka polskiego.

Słownik imion zawiera hasła w porządku alfabetycznym. Jako hasło podstawowe przyjmuję urzędową formę imienia ukraińskiego, którą podaję w transkrypcji, a następnie w nawiasie (kursywa) podaję pochodzenie imienia. Pozostałe antroponimy oddzielone znakiem [//] zawierają wyłącznie formy imion zanotowane na nekropolii w Baniach Mazurskich w pisowni oryginalnej. 


\begin{tabular}{|c|c|c|c|c|c|c|c|c|c|c|c|}
\hline$\stackrel{\tilde{E}}{\tilde{E}}$ & $\hat{n}$ & fo & $\hat{n}$ & $\hat{\imath}$ & ㄱ & 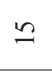 & 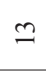 & 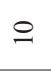 & $a$ & $\infty$ & $\hat{\tilde{\lambda}}$ \\
\hline \multirow{2}{*}{$\frac{2}{\tilde{n}}$} & 吕 & $\begin{array}{l}\stackrel{0}{0} \\
0\end{array}$ & $\frac{\stackrel{0}{0}}{i}$ & $\begin{array}{l}\stackrel{0}{0} \\
0 \\
0\end{array}$ & 官 & ठ̊. & $\stackrel{0}{0}_{0}^{\circ}$ & $\begin{array}{l}\dot{0}^{\circ} \\
\dot{0}\end{array}$ & $\stackrel{\circ}{\Rightarrow}$ & $\begin{array}{l}\text { in } \\
\text { in }\end{array}$ & \multirow[b]{2}{*}{$\nabla$} \\
\hline & 0 & 0 & - & 0 & - & 0 & 0 & 0 & - & - & \\
\hline \multirow{2}{*}{$\tilde{\sigma}}$. & $\stackrel{\circ}{\circ}$ & ठें & $\frac{\partial^{\circ}}{\infty}$ & ठ̊. & 官 & ठें & $\dot{0}_{0}^{\circ}$ & $\begin{array}{l}\circ \\
\stackrel{0}{0}\end{array}$ & $\ddot{0}_{0}^{\circ}$ & ठㅇ. & \multirow[b]{2}{*}{$=$} \\
\hline & $\nabla$ & 0 & $m$ & $\sim$ & - & 0 & 0 & - & 0 & 0 & \\
\hline \multirow{2}{*}{\begin{tabular}{l}
0 \\
\multirow{2}{*}{} \\
2
\end{tabular}} & $\begin{array}{l}\stackrel{0}{ } \\
\text { in }\end{array}$ & $\begin{array}{l}\stackrel{\circ}{+} \\
\stackrel{+}{+}\end{array}$ & ì & 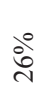 & $\begin{array}{l}\dot{0} \\
\dot{0} \\
\dot{0}\end{array}$ & $\stackrel{\circ}{\circ}$ & $\stackrel{0}{0}_{0}^{\circ}$ & $\dot{0}_{0}^{\circ}$ & $\stackrel{0}{0}_{0}^{\circ}$ & $\begin{array}{l}{ }_{0}^{\circ} \\
0\end{array}$ & \multirow[b]{2}{*}{ 드 } \\
\hline & $m$ & $N$ & in & 0 & - & 0 & 0 & 0 & 0 & 0 & \\
\hline \multirow{2}{*}{ ڤે } & $\begin{array}{l}{ }^{0} \\
\text { nn } \\
\text { m. }\end{array}$ & $\dot{0}_{0}^{\circ}$ & ठ̊. & $\stackrel{\circ}{\stackrel{0}{े}}$ & $\dot{0}_{0}^{\circ}$ & $\dot{b}_{0}^{\circ}$ & $\dot{0}_{0}^{\circ}$ & ठें & $\dot{0}_{0}^{\circ}$ & 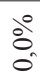 & \multirow[b]{2}{*}{$\sigma$} \\
\hline & $N$ & 0 & 0 & - & 0 & - & 0 & 0 & 0 & 0 & \\
\hline \multirow{2}{*}{$\bar{\sigma} \underset{\sigma}{\sigma}$} & $\begin{array}{l}\stackrel{0}{0} \\
\partial \hat{े}\end{array}$ & $\begin{array}{l}\stackrel{\circ}{m} \\
\text { ले }\end{array}$ & $\begin{array}{l}\stackrel{0}{0} \\
\stackrel{n}{n}\end{array}$ & $\begin{array}{l}\stackrel{0}{\circ} \\
\dot{m}\end{array}$ & $\begin{array}{l}\stackrel{0}{0} \\
\text { ì }\end{array}$ & $\begin{array}{l}\dot{0} \\
\dot{0}\end{array}$ & $\begin{array}{l}\stackrel{0}{0} \\
\text { jे }\end{array}$ & $\begin{array}{l}\stackrel{0}{0} \\
\stackrel{0}{0}\end{array}$ & $\begin{array}{l}\stackrel{\circ}{ } \\
\text { ते }\end{array}$ & $\begin{array}{l}\delta^{\circ} \\
\stackrel{0}{0}\end{array}$ & \multirow[b]{2}{*}{$\overline{6}$} \\
\hline & $=$ & $\cong$ & in & $\infty$ & $n$ & $m$ & $m$ & - & N & $N$ & \\
\hline \multirow{2}{*}{$\frac{\text { ล }}{\sigma}$} & 号 & $\stackrel{\stackrel{\circ}{+}}{\stackrel{+}{+}}$ & $\begin{array}{l}\stackrel{0}{ } \\
\text { m } \\
n\end{array}$ & $\begin{array}{l}\stackrel{\circ}{ } \\
\stackrel{2}{+}\end{array}$ & $\dot{0}_{0}^{\circ}$ & $\begin{array}{l}0 \\
\dot{0} \\
i\end{array}$ & iें & 官 & $\stackrel{\circ}{\Rightarrow}$ & $\stackrel{0}{0}_{0}^{\circ}$ & \multirow[b]{2}{*}{$\because$} \\
\hline & $\nabla$ & $\sim$ & in & - & 0 & - & - & 0 & - & 0 & \\
\hline \multirow{2}{*}{$\stackrel{\Xi}{\sigma}$} & $\begin{array}{l}\stackrel{0}{ } \\
\text { in } \\
\stackrel{\sim}{N}\end{array}$ & $\begin{array}{l}\text { iे } \\
\text { in } \\
\text { nn }\end{array}$ & $\begin{array}{l}\stackrel{0}{ } \\
\text { i }\end{array}$ & $\begin{array}{l}\stackrel{0}{ } \\
\stackrel{\text { I }}{=}\end{array}$ & $\begin{array}{l}\delta_{0}^{\circ} \\
\text { 8. }\end{array}$ & $\begin{array}{l}\stackrel{0}{ } \\
\stackrel{\text { iे }}{0}\end{array}$ & $\begin{array}{l}\stackrel{0}{0} \\
\dot{+} \\
\infty \\
m\end{array}$ & $\begin{array}{l}\stackrel{0}{ } \\
\stackrel{f}{q}\end{array}$ & $\begin{array}{l}\dot{m}^{\circ} \\
\hat{m}^{2}\end{array}$ & $\begin{array}{l}\text { 胥 } \\
\text { ñ }\end{array}$ & \multirow[b]{2}{*}{$F$} \\
\hline & \pm & $\stackrel{0}{ }$ & $a$ & $\nabla$ & $ㅇ$ & $n$ & in & $\nabla$ & $n$ & $n$ & \\
\hline \multirow[t]{2}{*}{$\stackrel{\text { ڤે }}{\circ}$} & 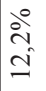 & $\begin{array}{l}\stackrel{\circ}{ }^{2} \\
\text { in }\end{array}$ & $\begin{array}{l}{ }_{0}^{\circ} \\
\infty \\
0\end{array}$ & ڤें & $\begin{array}{l}\dot{0}^{\circ} \\
\text { in }\end{array}$ & $\begin{array}{l}\text { ले } \\
\text { ஸे }\end{array}$ & $\begin{array}{l}\stackrel{\circ}{2} \\
\stackrel{n}{n}\end{array}$ & $\begin{array}{l}\text { ठें } \\
\text { ळे }\end{array}$ & $\stackrel{\circ}{\Rightarrow}$ & $\begin{array}{l}\text { in } \\
\text { i }\end{array}$ & \multirow[b]{2}{*}{ ते } \\
\hline & $r$ & $r$ & $\nabla$ & - & - & $\sim$ & $N$ & $n$ & - & - & \\
\hline \multirow[t]{2}{*}{$\begin{array}{ll}\infty & \infty \\
\infty & \infty \\
\infty & \infty\end{array}$} & $\begin{array}{l}\stackrel{0}{0} \\
\infty^{\circ}\end{array}$ & $\begin{array}{l}\stackrel{\circ}{े} \\
\text { ì }\end{array}$ & $\begin{array}{l}\stackrel{0}{0} \\
0_{0}^{\circ}\end{array}$ & $\stackrel{\circ}{0}_{0}^{\circ}$ & $\dot{0}_{0}^{\circ}$ & $\begin{array}{l}\text { bे } \\
\text { iे }\end{array}$ & $\stackrel{\circ}{\circ}$ & $\begin{array}{l}\stackrel{0}{0} \\
\stackrel{0}{0}\end{array}$ & $\stackrel{\circ}{=}$ & iे & \multirow[b]{2}{*}{$\stackrel{\infty}{\mathscr{0}}$} \\
\hline & in & - & $\nabla$ & 0 & 0 & + & - & - & - & - & \\
\hline \multirow{2}{*}{$\underset{\infty}{\mathbb{\infty}} \underset{\infty}{\stackrel{\infty}{\infty}}$} & $\stackrel{\stackrel{0}{2}}{=}$ & $\begin{array}{l}\stackrel{\circ}{\mathrm{i}} \\
\text { ì }\end{array}$ & $\frac{\stackrel{0}{i}}{i}$ & $\stackrel{\circ}{0}$ & $\begin{array}{l}\delta_{0}^{\circ} \\
0\end{array}$ & $\stackrel{\circ}{\circ}$ & $\stackrel{0}{0}_{0}^{\circ}$ & $\begin{array}{l}\stackrel{0}{0} \\
\dot{0}\end{array}$ & $\begin{array}{l}0 \\
0 \\
0\end{array}$ & $\begin{array}{l}\delta_{0}^{\circ} \\
0\end{array}$ & \multirow[b]{2}{*}{$m$} \\
\hline & - & - & - & 0 & 0 & 0 & 0 & 0 & 0 & 0 & \\
\hline \multirow{2}{*}{$\stackrel{\infty}{\infty}$} & $\stackrel{0}{0}_{0}^{\circ}$ & ڤें & $\ddot{0}_{0}^{\circ}$ & $\dot{0}_{0}^{\circ}$ & $\begin{array}{l}\circ \\
\text { in }\end{array}$ & bें & $\dot{0}_{0}^{\circ}$ & 吕 & $\dot{0}_{0}^{\circ}$ & $8_{0}^{\circ}$ & \multirow[b]{2}{*}{$m$} \\
\hline & 0 & - & 0 & 0 & - & - & 0 & 0 & 0 & 0 & \\
\hline ஓి & 0 & 0 & 0 & 0 & 0 & 0 & 0 & 0 & 0 & 0 & 0 \\
\hline 营 & 墕 & 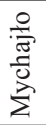 & 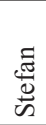 & 离 & 莣 & 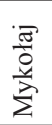 & $\begin{array}{l}\dot{\bar{\theta}} \\
\dot{0} \\
\stackrel{0}{0}\end{array}$ & 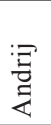 & 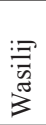 & 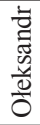 & $\begin{array}{c}\stackrel{\varpi}{\Xi} \\
\stackrel{\Xi}{\Xi}\end{array}$ \\
\hline
\end{tabular}




\begin{tabular}{|c|c|c|c|c|c|c|c|c|c|c|c|}
\hline 竭 & in & $\stackrel{g}{f}$ & $\tilde{m}$ & $=$ & $\stackrel{0}{0}$ & 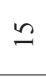 & $a$ & 0 & $n$ & $n$ & $\stackrel{\overbrace{}}{\sim}$ \\
\hline \multirow{2}{*}{ 尝 } & $\begin{array}{l}\stackrel{0}{0} \\
\dot{0}^{\circ}\end{array}$ & $\begin{array}{l}\stackrel{0}{0} \\
\text { i }\end{array}$ & $\stackrel{\circ}{\circ}$ & $\dot{0}_{0}^{\circ}$ & $\check{O}_{0}^{\circ}$ & $\dot{0}_{0}^{\circ}$ & $\stackrel{\partial}{=}$ & $\stackrel{0}{0}_{0}^{\circ}$ & $\dot{0}_{0}^{\circ}$ & $\begin{array}{l}0 \\
0 \\
0\end{array}$ & \\
\hline & $\nabla$ & - & 0 & 0 & 0 & 0 & - & 0 & 0 & 0 & 6 \\
\hline \multirow{2}{*}{ 㔯 } & ठ̊. & ठें & ठें & $\stackrel{\stackrel{0}{\ddagger}}{=}$ & $\begin{array}{l}\text { ठें } \\
\text { Oे }\end{array}$ & 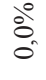 & ठें & लें & $\begin{array}{l}80 \\
0\end{array}$ & $\begin{array}{l}\text { oे } \\
0 \\
0\end{array}$ & \\
\hline & $m$ & 0 & 0 & $N$ & 0 & 0 & 0 & $N$ & 0 & 0 & $r$ \\
\hline \multirow{2}{*}{ ఏ゚ } & 吕 & $\begin{array}{l}\stackrel{0}{0} \\
\text { i }\end{array}$ & $\begin{array}{l}\text { ठे } \\
\text { ले }\end{array}$ & $\stackrel{0}{0}_{0}^{\circ}$ & $\stackrel{0}{0}_{0}^{\circ}$ & $\begin{array}{l}\delta_{0}^{\circ} \\
0\end{array}$ & $\begin{array}{l}\circ \\
0\end{array}$ & $\begin{array}{l}\stackrel{0}{ } \\
\dot{m}^{m}\end{array}$ & $\begin{array}{l}0 \\
0\end{array}$ & $\begin{array}{l}\stackrel{0}{0} \\
\text { o. } \\
\text { ㅇ. }\end{array}$ & \\
\hline & 0 & - & - & 0 & 0 & 0 & 0 & $\sim$ & 0 & - & $n$ \\
\hline \multirow{2}{*}{ ڤે ڤ̊ } & $\begin{array}{l}\dot{\theta}^{\circ} \\
0\end{array}$ & $\begin{array}{l}\dot{0} \\
\text { i }\end{array}$ & $\begin{array}{l}\text { Oें } \\
\text { Oे }\end{array}$ & $\begin{array}{l}\dot{\theta}_{0}^{\circ} \\
0\end{array}$ & $\begin{array}{l}\stackrel{0}{0} \\
\dot{0}\end{array}$ & $\begin{array}{l}\dot{\theta}_{0}^{\circ} \\
0\end{array}$ & $\begin{array}{l}\dot{0}_{0}^{\circ} \\
0\end{array}$ & $\begin{array}{l}\dot{0} \\
\dot{0}\end{array}$ & $\begin{array}{l}\dot{0} \\
\dot{0}\end{array}$ & $\begin{array}{l}80 \\
0 \\
0\end{array}$ & \\
\hline & 0 & - & 0 & 0 & 0 & 0 & 0 & 0 & 0 & 0 & - \\
\hline \multirow{2}{*}{$\bar{\sigma} \underset{\sigma}{\sigma}$} & $\begin{array}{l}0 \\
0 \\
0 \\
0\end{array}$ & $\begin{array}{l}\stackrel{\circ}{+} \\
\text { ì }\end{array}$ & $\frac{\stackrel{0}{\check{c}}}{\mathrm{c}}$ & $\stackrel{\stackrel{\circ}{\rightleftarrows}}{=}$ & $\begin{array}{l}\stackrel{0}{ } \\
\text { in } \\
\text { a }\end{array}$ & $\begin{array}{l}\stackrel{0}{0} \\
\text { ठें }\end{array}$ & $\begin{array}{l}\stackrel{0}{ } \\
\text { ते }\end{array}$ & ले & $\begin{array}{l}\stackrel{0}{0} \\
\dot{q}\end{array}$ & $\begin{array}{l}\circ \\
0_{0}^{\circ} \\
0\end{array}$ & \\
\hline & $\infty$ & $=$ & $\nabla$ & $N$ & $\sim$ & $m$ & $v$ & $N$ & $N$ & 0 & ల \\
\hline \multirow{2}{*}{$\frac{n}{\sigma}$} & ठें & $\begin{array}{l}\stackrel{0}{\circ} \\
\dot{+}\end{array}$ & $\begin{array}{l}\text { ठें } \\
\text { aे }\end{array}$ & $\begin{array}{l}\otimes_{0}^{\circ} \\
n^{\circ}\end{array}$ & 今े & $\dot{b}_{0}^{\circ}$ & $\stackrel{\circ}{0}$ & $\stackrel{\circ}{\circ}$ & $\stackrel{0}{0}_{0}^{\circ}$ & $\begin{array}{l}0 \\
0 \\
0\end{array}$ & \\
\hline & 0 & $N$ & $n$ & - & - & - & 0 & 0 & 0 & 0 & $\infty$ \\
\hline \multirow{2}{*}{ ఏ్ } & 吕 & $\begin{array}{l}\stackrel{0}{0} \\
\infty \\
\dot{f}\end{array}$ & $\stackrel{\circ}{i n}$ & $\begin{array}{l}\stackrel{\circ}{\circ} \\
\stackrel{f}{f}\end{array}$ & $\frac{\stackrel{\circ}{r}}{\stackrel{\gamma}{\sigma}}$ & $\begin{array}{l}\dot{b}_{0}^{\circ} \\
\text { iे }\end{array}$ & $\begin{array}{l}\dot{b}_{0}^{\circ} \\
\text { i. }\end{array}$ & $\begin{array}{l}\circ \\
0\end{array}$ & $\begin{array}{l}\stackrel{0}{0} \\
\dot{q}\end{array}$ & $\begin{array}{l}0 \\
8 \\
0 \\
8 \\
0\end{array}$ & \\
\hline & तิ & ㄱ. & $\Xi$ & $\infty$ & $r$ & $\nabla$ & 0 & 0 & $\sim$ & $m$ & $\hat{\infty}$ \\
\hline \multirow{2}{*}{ ڤે } & ठें & 仓ें & 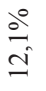 & $\begin{array}{l}\dot{b}_{0}^{\circ} \\
\stackrel{=}{=}\end{array}$ & ڤें & $\stackrel{\stackrel{े}{\circ}}{\stackrel{m}{n}}$ & ठें & ठे. & ठें & $\begin{array}{l}0 \\
8 \\
0 \\
0 \\
\hat{i}\end{array}$ & \\
\hline & $n$ & $\infty$ & + & $n$ & - & $N$ & 0 & 0 & 0 & - & $\tilde{N}$ \\
\hline \multirow[t]{2}{*}{$\begin{array}{l}\stackrel{\infty}{\infty} \\
\infty \\
=\end{array}$} & $\begin{array}{l}\stackrel{0}{0} \\
\text { â }\end{array}$ & $\begin{array}{l}\text { iे } \\
\text { i }\end{array}$ & 吕 & $\begin{array}{l}{ }_{0}^{\circ} \\
\text { in }\end{array}$ & $\frac{\stackrel{\text { ̀े }}{m}}{\text { m. }}$ & $\begin{array}{l}\dot{0}^{\circ} \\
\text { ᄋे }\end{array}$ & $\stackrel{\circ}{\circ}$ & $\begin{array}{l}\circ \\
0\end{array}$ & $\begin{array}{l}\dot{0}^{\circ} \\
\stackrel{\text { iे }}{ }\end{array}$ & $\begin{array}{l}0 \\
0 \\
0\end{array}$ & \\
\hline & 6 & - & $\sim$ & - & in & $m$ & 0 & 0 & - & 0 & 9 \\
\hline \multirow{2}{*}{$\underset{\infty}{\infty} \underset{\infty}{\infty}$} & 吕 & $\begin{array}{l}\text { ठें } \\
\text { +े }\end{array}$ & ठ̊. & $\delta_{0}^{0}$ & $\dot{0}_{0}^{\circ}$ & $\delta_{0}^{\circ}$ & $\dot{0}_{0}^{\circ}$ & $\begin{array}{l}0 \\
\delta_{0}^{\circ}\end{array}$ & $\begin{array}{l}\circ \\
\text { Oे }\end{array}$ & $\begin{array}{l}\stackrel{0}{0} \\
0 \\
0\end{array}$ & \\
\hline & in & $N$ & $N$ & 0 & 0 & 0 & 0 & 0 & 0 & 0 & $a$ \\
\hline \multirow[t]{2}{*}{ ஜ̂ } & $\begin{array}{l}\text { वें } \\
\text { i }\end{array}$ & $\begin{array}{l}\stackrel{8}{\circ} \\
+\end{array}$ & $\begin{array}{l}\text { ठ̊. } \\
\text { ठ }\end{array}$ & $\stackrel{8}{0}_{0}^{\circ}$ & $\stackrel{\circ}{\circ}$ & $\begin{array}{l}\stackrel{0}{m} \\
\stackrel{n}{n}\end{array}$ & $\stackrel{\circ}{\circ}$ & $\begin{array}{l}0 \\
0\end{array}$ & $\begin{array}{l}\circ \\
0\end{array}$ & $\begin{array}{l}\circ \\
0 \\
0 \\
0\end{array}$ & \\
\hline & - & $N$ & 0 & 0 & 0 & $N$ & 0 & 0 & 0 & 0 & in \\
\hline 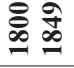 & 0 & 0 & 0 & 0 & 0 & 0 & 0 & 0 & 0 & 0 & 0 \\
\hline 节 & : & 要 & 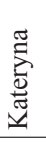 & $\stackrel{\mathbb{3}}{3}$ & $\begin{array}{l}: \frac{\pi}{2} \\
\frac{0}{0} \\
\frac{\pi}{0} \\
\frac{\pi}{\pi} \\
\tilde{D}\end{array}$ & 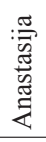 & 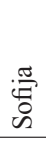 & 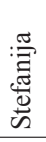 & 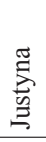 & $\frac{\frac{\pi}{4}}{\omega}$ & $\begin{array}{l}\text { : } \\
\text { ڤ } \\
\end{array}$ \\
\hline
\end{tabular}




\section{Słownik imion}

ADAM (hebr.): Адам (ukr.; ros.) // Апам

ADOLF (germ.): Адольф (ukr.; ros.)

AGATA (gr.): Ага́та (ukr.; ros.) // Ага́фiя (ukr.)

ANASTASIJA (gr.): Анастазія // Анастаса // Анастазя // Анастазиа

ANDRIJ (gr.): Андрій (ukr.) // Анdріи

ANNA (hebr.): Анна (ukr.; ros.)

ANTONIJ (łac.): Антоній (ukr.)

BOHDAN (gr.): Богдан (ukr.; ros.)

BOŽENA (czes.): Божена (ukr.; ros.)

CHRYSTYNA (gr.): Христина (ukr.)

DANUTA (lit.): Dанута [imię pochodzenia litewskiego popularne w Polsce, nie używane na Ukrainie]

DANYŁO (hebr.): Данило (ukr.; starorosyjskie) // Даниїл

DARIJ (gr..): Dap'iуш

DARIJA (gr.): Дарія (ukr.; rzadsza wersja imienia niż Дарина)

DMYTRO (gr.) od DEMETRJUŠ: Дмитро (ukr.) // Dимитро // Дмутро // Dимитрій EMIL (lac.): Еміл

EMILIJA (łac.): Еміля

FENNA ( $g r$.): Фенна prawdopodobnie od formy starotestamentowej Фененна ${ }^{4}$

HNAT (łac.): Гнат (ukr.)

HRYHORIJ (gr.): Григорій (ukr.) // Григоріи

ILLJA (hebr.): Ілько (ukr.)

IRENA ( $g r$.$) : Ірена (ukr.) // Јрина$

IWAN (hebr.): Іван (ukr.) // Јван // Ів’ан // Јвась // Иван (ros.)

JAROSŁAW (słowian.): Ярослав (ukr.; ros.) // Яарослав

JAROSŁAWA (słowian.): Ярослава (ukr.; ros.)

JEFROSYNIJA (gr.): Евфрузина // Єфросинія (ukr.) // Єфрузина

JEFYMIJA ( $g r$.$) : Евфемя$

JEWA (hebr.): Ева (ros.)

JEWDOKIJA $(g r$.$) : Эвдокія$

4 Zdrobnienie Фенна może pochodzić też od Агриппина, Сосфен, Трифена, Фемисткл, Феоген, Феогний, Феогния, Феогност, Феодосия, Феона, Феонилла, Феопент, Феопист, Феостирикт. 
JEWHEN (gr.): Евген

JEWHENIJA ( $g r$.$) : Евгенія // Евгеня$

JEWSTACHIJ (gr.): Евстахи // Евстах $u$

JEWSTACHIJA $(g r$.$) : Евстахія$

JOSYP (stowian.): Йосип (dawne ukr.) // Иосф // Йосиф (ukr.)

JULIJA (łac.): Юлія (ukr.) // Юлья

JURIJ (gr.): Юріи // Юрій (ukr.) // Юури

JUSTYNA (łac.): Юстина (ukr.), Юсина

JUZEFA (stowian.): Јузефа

KATERYNA (gr.): Екатерина (ros.) // Катарина // Катерина (ukr.; ros.) // Катерина // Катаруна // Катеріиа

KUŹMA ( $g r$.): Косма (staroruska wersja) // Кузьма (ukr.)

LUBAWA; LUBA (stowian.): Люба zdr. od Любава // Любов // Любомила // Любомира

ŁESIA: Леся (ukr.) zdrobnienie od Лариса (gr.) // Олександра // Олександрина // Олеся // Ольга

MAKARY (gr.): Макар (ukr.; ros.)

MARIJA (gr.): Маря (ukr.) // Марія (ukr. - starsza wersja); // Mapi // Mapia (pol.) // Маруся (zdrobnienie ukr.) // Марися (zdrobnienie pol.)

МYCHАJŁO (hebr.): Миха́йло (ukr.) // Михаіл // Міхапло // Міхаило // Міхал // Михаіло // Міхайло // Михаїл // Михаило

MYKOŁАЈ (gr.): Миколай (ukr.) // Міколай // Микола (ukr.) // Миколаи // Миколап // Микіта

MYROSŁAW (slowian.): Мирослав (ukr.; ros.)

NADIJA (stowian.): Надія (ukr.)

NATALIJA (lac.): Наталя (ukr.) // Наталія (ukr.)

NAZAR (hebr.): Назáp (ukr.)

OŁEKSA ( $g r$.): Олекса (ukr.) // Олекс

OŁEKSANDR (gr.): Александр (ros.) // Александер (pol.) // Олександр (ukr.); OŁEKSANDRA (gr.): Алекса́ндра // Олекса́ндра (ukr.)

OŁENA ( $g r$.): Олена (ukr.)

PAMFIŁ (gr.): Памфі́л (ukr.; ros.)

PANTEŁEJMON ( $g r$.): Панько (dawniej Пантелеймон)

PARASKOWIJA (gr.): Параскевія // Параскевя // Рараскевя // Рараскевія (białorus.) // Параскєвія

PAWŁYNA (

PAWŁO (tac.): Павло (ukr.) // Павел (ros.) 
PELAGIJA ( $g r$.$) : Пелагія (ukr.)$

PETRO (gr.): Петro // Петро (ukr.) // Петрусь (zdrobnienie ukr.)

PETRUNELIA (łac.): Петронеля

PROKIP ( $g r$.): Прокіп (ukr.)

PYŁYP (gr.): Пилип (ukr.)

ROMAN (lac.): Роман (ukr.; ros.)

ROZALIJA (tac.): Розалія (ukr.)

SEMEN (hebr.): Сенько (zdrobnienie)

STANISŁAW (stowian.): Станіслав (ukr.)

STEPAN; STEFAN (gr.): Стифан // Стефан (ukr.; ros.) // Стефаn // Степан (ukr.; ros.)

STEFANIJA ( $g r$.): Степанія (ukr. dawna forma imienia)

SYMEON (hebr.): Симеон (ros.) // Семеон

TADEJ (hebr.): Тадзіо

TEKLA (gr.): Текля (ukr.)

TEODOR ( $g r$.): Теодо́p (ukr.; ros.) // Teodop;

TEODORA ( $g r$.$) : Теодора (ukr.)$

TEODOZIJA ( $g r$.$) : Теодозія (ukr.) // Теодозя (ukr.)$

TETJANA (łac.): Таціянна // Татянна // Татіяна // Татяна

CHOMA; TOMA (hebr.): Томаш (pol.)

TROXYM (gr.): Трофім

ULANA (lac.): Уляна (ukr.) // Ульяна (ros.)

WARWARA (gr.): Варвápa (ukr.; ros.)

WASYL (gr.): Василь (ukr.)

WERONIKA ( $g r$.): Вероніка (ukr.)

WIRA (stowian.): może być też zdr. od WERONIKA: Bipa (ukr.) // Бepa

WOŁODYMYR (stowian.): Володимир // Володимир (ukr.)

SOFIJA (gr.): Софія // Зофія // Зофіа // Софіа

ZINOWIJ (gr.): Зіно́вій (ukr.)

\section{Bibliografia}

ABRAmowicz Z., 1988, Religia a wybór imienia. Imiona ludności wyznania prawosławnego na Białostocczyźnie w latach 1915-1939, Roczniki Humanistyczne XXXVI, z. 7, 1988, s. 17-32.

ŁEsIów M., 1988, Wschodniosłowiańskie nazewnictwo osobowe po 988 i jego wpływ na antroponimikę krajów sąsiednich, Roczniki Humanistyczne XXXVI, z. 7, s. 7-15. 
Maliszewska A., 1993, Nazwy osobowe ludności łemkowskiej (na podstawie materiałów z nagrobków), Onomastica XXXVIII, s. 169-201.

Mazurowska A., 2005, Sytuacja językowa w miejscowości Banie Mazurskie (komputeropis). Referat wygłoszony na Międzynarodowej Studenckiej Konferencji Naukowej w Lodzi (10-11 V 2005) pod hasłem Język polski u progu XXI wieku. Tekst oddany do druku w roku 2006.

Метровский Н. А., 2000, Словарь русских личных имен, Москва: Русский язык.

Michna E., 1995, Łemkowie. Grupa etniczna czy naród, Kraków: Nomos.

RIEGer J., 1995, Slownictwo i nazewnictwo temkowskie, Warszawa: Semper.

Скрипник Л. Г., ДзятківськА Н. П., 1996, Власні імена людей, Москва: Наукова думка.

Stownik imion, 1975, oprac. W. Janowowa, A. Skarbek, B. Zbijowska, J. Zbiniowska, Wrocław: Zakład Narodowy im. Ossolińskich.

Stieber Z., 1982, Dialekt Łemków: fonetyka i fonologia, Wrocław: Zakład Narodowy im. Ossolińskich.

Szymaniak S. A., 2003, Antroponimia temkowska okolic Komańczy zapisana w księgach parafialnych na nagrobkach (w Komańczy i okolicach). Praca magisterska napisana pod kierunkiem K. Szcześniak, Gdańsk (komputeropis).

Wallerand M., 1977, Antroponimia okolic Bań Mazurskich. Praca magisterska napisana pod kierunkiem L. Moszyńskiego, Gdańsk (maszynopis).

Wolnicz-PawŁowska E., 1993, Antroponimia temkowska na tle polskim i stowackim $X V I-X X$ wiek, Warszawa: Slawistyczny Ośrodek Wydawniczy.

\section{Следы прошлого скрытые в эпитафиях на нагробных камнях села Бане Мазурские}

(изложение)

Темой статьи является анализ имён записанных в ономатологических эпитафиях на коммунальном кладбище в Банях Мазурских и попытка ответить на вопрос, какую информацию передают нам они о погребеннох там умерших.

В введение дана этнолингвистическая ситуация щугаемого региона выясняющая, почему и откуда на земл'ях северно-восточной Польши, особенно в венгожевском и голдапском повятах оказались переселенцы операции „В” („Висла”) проведённой властями ПН'Р в 1947-1948 годах.

Основную часть реферата составляет анализ форм имён украинцев (Бойков и Лемков), которые были записаны гражданкой на местном кладбище.

Вниманию заслуживают разнообразные ошибки появляющиеся в графии, например в написании имён выступает путаница польских, украинских и русских букв, также как и письменных и печатных букв. Основной исследовательской задачей статьи является попытка ответа на вопрос о причине такого разнообразия форм исследуемых антропонимов. 